\title{
Scale Insects and Mealy Bugs Associated with Citrus Trees in El Beheira Governorate, Egypt
}

\author{
Moursi, Khadiga, S.; ${ }^{1}$ Mesbah,H.A.; ${ }^{2}$ El-Sayed, Nagda, A. ${ }^{2}$ and Omr, M. Abdel Wanees ${ }^{2}$
}

\begin{abstract}
The obtained results revealed that a total of twelve scale insect and mealy bug species following nine genera belonging to four families of supper family Coccoidea infesting four varieties of citrus trees in El Beheira Governorate were recorded and identified during the period of study from 2011 to 2013.
\end{abstract}

\section{INTRODUCTION}

The citrus fruits, because of its attractiveness, good taste and nutritive value, has gained popularity with peoples all over the world. Trees of certain citrus varieties are attractive in their own right and have been used in ornamental landscaping. The leaves of particular varieties are used as a spice, particularly with chicken dishes and in some cultures, the rind is used medicinally (Gill, 1997).

In Egypt, citrus is the most important fruit as far as its acreage production and exportation potentials are concerned (El-Kassas, 1984).

Insect pests are regarded as one of the important injurious factors responsible for deterioration of citrus trees in Egypt. Amongst, scale insects and mealy bugs constitute one of the common insect pests of citrus.

The present work aims to survey and identification of scale insects and mealy bugs that associated with four varieties of citrus in Abu al Matamir area, El Beheira Governorate and compares the susceptibility of these varieties to infestation during two successive growing seasons.

\section{MATERIALS AND METHODS}

In order to survey scale insects and mealy bugs associating with citrus trees in El Beheira Governorate, private orchard was chosen for study at Abu al Matamir. The chosen farm included many varieties of citrus as:

1. The Mandarin orange, Citrus reticulata

2. The Sweet orange, Citrus sinensis

In the present study, three varieties were chosen:

A-Succari orange

B- Navel orange

C-Baladi orange
Survey and inspection of scale insects and mealybugs were started from February $11^{\text {th }}$, 2011 till January $25^{\text {th }}$, 2013. The trees received the same horticultural practices. From each plant variety, eight trees were chosen to survey the scale insects and mealybugs that attacking their branches and leaves. Ten leaves and three small branches (About 15-20 cm long) were picked out monthly at random from each direction of each tree.

Leaves and branches were put in cloth bags and transported directly to the laboratory for classifying the detected species using a stereoscopic binocular microscope. For classifying the inspected species, slide preparations of adult females were made and examined microscopically at a power of 10-15 X and identified by scale insects and mealybugs division, plant protection institute, agricultural research center Dokki, Giza, Egypt.

\section{RESULTS AND DISCUSSION}

A. Species composition and distribution of scale insects and mealy bugs on four verities of citrus trees during two successive years (Feb. 2011- Jan. 2013) in El-Beheira Governorate.

The exhibited data in Table (1) asserted that a total of twelve scale insect and mealy bug species following nine genera belonging to four families of supper family Coccoidea were infesting the four studied varieties of citrus trees in El-Beheira Governorate during the period of the study. The collected scale insects and mealy bugs could be listed taxonomically as follows:

\section{Family: Coccidae}

1. The Florida wax scale, Ceroplastes floridensis Comstock

2. Brown soft scale, Coccus hesperidum hesperidum $\mathrm{L}$

3. Long Brown soft scale, Coccus longulus (Douglas)

4. Hemispherical soft scale, Saissetia coffeae (Walker)

5. Mediterranean Black scale, Saissetia oleae (Olivier)

Family: Diaspididae

1. California red scale, Aonidiella aurantii Comstock

2. Black scale, Chrysomphalus aonidum (Linnaeus)

\footnotetext{
${ }^{1}$ Plant Protection Research Institute, ARC, Alexandria

${ }^{2}$ Faculty of Agriculture, Saba Basha, Plant Protection

Department, Alexandria University, Egypt.

Received August 8, 2013, Accepted September 15, 2008
} 
Table 1. Distribution of the scale insects and mealybugs associated with four varieties of citrus during the elapsing period from 2011-2013 in El Beheira Governorate

\begin{tabular}{|c|c|c|c|c|}
\hline \multirow[b]{2}{*}{ Inspected species } & \multicolumn{4}{|c|}{ Citrusvarieties } \\
\hline & Succari & Baladi & Navel & Mandarin \\
\hline Ceroplastes floridensis & $*$ & $*$ & $*$ & $*$ \\
\hline Coccus hesperidum & $*$ & $*$ & $*$ & $*$ \\
\hline Coccus longulus & - & - & $*$ & $*$ \\
\hline Saissetia coffeae & $*$ & $*$ & $*$ & $*$ \\
\hline Saissetia oleae & - & $*$ & - & - \\
\hline Aonidiella aurantii & $*$ & $*$ & $*$ & $*$ \\
\hline Chrysomphalus aonidum & $*$ & $*$ & $*$ & $*$ \\
\hline Lepidosaphes beckii & $*$ & $*$ & $*$ & $*$ \\
\hline Parlatoria pergandii & $*$ & $*$ & $*$ & $*$ \\
\hline Icerya purchasi & $*$ & $*$ & $*$ & $*$ \\
\hline Icerya seychellarum & $*$ & $*$ & $*$ & $*$ \\
\hline Planococcus citri & $*$ & $*$ & $*$ & $*$ \\
\hline Total detected spp/citrus varieties & 10 & 11 & 11 & 11 \\
\hline
\end{tabular}

3. Citrus mussel scale, Lepidosaphes beckii (Newman)

4. Chaff scale, Parlatoria pergandii (Comstock)

\section{Family: Monophlebidae}

1. Cottony Cushion scale, Icerya purchasi purchasi Maskell

2. Seychellarum mealybug, Icerya seychellarum seychellarum (Westwood)

\section{Family: Pseudococcidae}

1. Citrus mealy bug, Planococcus citri (Risso)

B. The occurrence date of Coccoidea species associated with four varieties of citrus during the period of study (Feb. 2011 till Jan., 2013).

\section{Family: Coccidae}

1. The Florida wax scale, Ceroplastes floridensis Comstock

Podoler et al. (1981) reported that C.floridensis attacks a great number of host plants especially citrus spp, and its main damage is due to the production of honeydew, which serves a substance for various sooty mould fungi. They also stated that sever infestation of citrus May result in culling of the intercrop, reduction of subsequent yield and serious injury to the trees.

In Egypt C.floridensis became a common pest of citrus trees and ornamental plants during the last few years, especially the humid areas at the northern of Egypt. It was first recorded in Egypt in 1905 on orange trees at kafer El-Dewar, El-Beheira (Willcocks, 1922). Hall (1923) mentioned that it was common in Lower Egypt, particularly in Alexandria and the coastal areas.

The presented result in tables $(2 \& 3)$ show that, Florida wax scale, C.floridensis was observed infesting the four citrus varieties all over the year except
September in the first growing season on Succari and Navel orange. In the second year, it disappeared in August on Succari and Navel orange in the first year while, in March on mandarin and April on succari, baladi and navel in the second year (Tables $2 \& 3$ ). Its ratio reached 4.53, 7.33, 5.06 and $12.58 \%$ on Succari, Baladi, Navel oranges and Mandarin, respectively in the first year. These ratios increased in the second year (Tables 2\&3).

It is worth to mention here that males have not been recorded and these agree with data of Hamon and Williams (1984).

2. Brown soft scale, Coccus hesperidum hesperidum L.

It is recorded and described in Egypt by Hall (1922) and Ezzat \& Hussien (1969), who listed its host plants in Egypt.

In the present work, it was recorded in the first year of study on Succari orange during the period of February to April and from September to January, disappeared in May to August with 2.69\% of infestation (Table 2). On Baladi orange it was found from February to May and from October to January, disappeared from July to September, with $3.01 \%$ but on Navel and Mandarin, it was $1.73 \%$ and $6.93 \%$, respectively.

In the second growing season, it was observed in few numbers on Succari orange, March, April on Baladi orange; February, March and November on Navel orange and during February, March and May, June on Mandarin. It reached less percentage on four varieties in the second year (Table3). 
This agree with the data obtained by Al-khaldy (2003) who showed that the presence of C.hespridum in few number without economic damage.

\section{Long Brown Scale, Coccus longulus (Douglas)}

It was described in Egypt by Hall (1922\&1923), Ezzat and Hussein (1969), Ezzat and Nada (1986)

The long brown scale was found infesting Navel orange in December 2011 and June, July 2012 while it was recorded on Mandarin in October 2011 with low mean number during the two years. (Tables, $2 \& 3$ ).

\section{Hemispherical scale, Saissetia coffeae (Walker)}

It was recorded and described in Egypt by Hall (1922, 1923), and Ezzat and Hussien (1969).

In the present study, the hemispherical scale, Saissetia coffeae was observed on Mandarin trees during April 2011 but in the second growing season, it observed on Succari and Baladi orange during April, on Navel orange in October and Mandarin trees in April and August 2012. The mean numbers were very low on the four species and varieties under study. (Tables, 2\&3)

\section{Olive soft scale, Saissetia oleae (Olivier)}

It was described in Egypt by Hall (1922\& 1923); and Ezzat \&Hussein (1969).

Tables (2\&3) show that the olive black scale infested Baladi orange in February, 2011 only in Abu al Matamir area, with low mean number (0.08).

\section{Family: Diaspididae}

\section{California red scale, Aonidiella aurantii (Maskell)}

It was recorded in Egypt by Hall (1922); Balachewsky (1932) and Ezzat (1959)

In the present work, it was recorded on all varieties under study all over the year except during April in the first growing season and during June in the second growing season on Mandarin trees. In the first growing season, the mean number were 13.84, 11.67, 11.99 and $15.55 \%$ on Succari, Baladi, Navel and Mandarin respectively. In the second year, these percentages decreased on Succari and Baladi but increased on Navel orange. It reached $12.58,14.29,14.01$ and $14.41 \%$ of total count insect on Succari, Baladi, Navel orange and Mandarin, respectively. (Tables 2\&3)

The data differ with that stated by Habib et al. (1972) who found that the mean minimum population of A.aurantii occurred on Mandarin (light infested) while the highest population was observed on grape fruit (heavy infested).

\section{Black scale, Chrysomphalus aonidum (Linnaeus)}

It was recorded in Egypt by Hall (1922) and Ezzat (1958)
In the present study, black scale was observed on all tested varieties during the two successive years. On Succari orange it disappeared in December, 2011 and September in the second year, on Baladi orange, it disappeared on January in the first growing season and from February to April in the second. (Tables 2\&3).

Considering Navel orange the black scale was not observed in September 2011, while on Mandarin trees, it disappeared in May, August, December and January, 2012 (Table 2) and on March, April and September in the second growing season $C$. aonidum represented 6.90, 11.36, 7.84 and $9.20 \%$ of total count on Succari, Baladi, Navel orange and Mandarin, respectively in the first year, while these ratios increased on baladi to $14.23 \%$ in the second year.

The obtained results are agree with those obtained by Habib and Attallah (1960) who found that orange Baladi was highly susceptible to infestation by C.ficus, (C.aonidium).

On the other hand, Wing-Feng (1999) reported that C.aonidium causes serious damage to citrus leaves in china in late May to early June, then in late July to august and late October to early November..

\section{The purple scale, Lepidosaphes beckii (Newman)}

L.beckii is considered as very common armoured scale insects infesting orange orchards in Alexandria Governorate. Heavy infestation causes chlorosis of leaves, defoliation, discoloration and poor maturation of the fruit and desiccation, weakening and dieback of the branches or even entire trees (Gill, 1997).

In the present study, (Tables $2 \& 3$ ) purple scale was observed on all tested varieties during the date of inspection of two growing season under study except on May on Baladi orange, in the first growing season.

In the first year, the mean number were $44.75,30.26$, 54.46 and $35.15 \%$ for Succari, Baladi; Navel oranges and Mandarin, respectively. These ratios were 48.03, $30.35,52.12$ and $39.93 \%$ of total count in the second year for the inspected citrus varieties and species, respectively. The data obtained is differ with that given by Hafez and Salama(1969) who reported that Baladi orange was highly susceptible to infestation by L.beckii, while the same result is agree slightly with that data which showed that Succari orange is highly susceptible to infestation with purple scale.

It is worth to mention here that, L.beckii represented the highest ratio of scale insects and mealybugs associated with citrus varieties under study in Abu al Matamir area. 
Table 2. Occurrence dates of scale insects and mealy bugs infested four varieties of citrus trees at El Beheira during 2011-2012

\begin{tabular}{|c|c|c|c|c|c|c|c|c|c|c|c|c|c|c|}
\hline \multirow[t]{2}{*}{ Coccoid sp. } & \multirow[b]{2}{*}{ Var. } & \multicolumn{12}{|c|}{ Months } & \multirow[t]{2}{*}{ Mean (\%) } \\
\hline & & Feb. & M. & A. & M. & J. & July & A. & S. & o. & $\mathbf{N}$. & D. & Jan. & \\
\hline \multirow{4}{*}{ Ceroplastes floridensis } & S. & $*$ & $*$ & $*$ & $*$ & $*$ & $*$ & - & $*$ & $*$ & $*$ & $*$ & $*$ & 4.53 \\
\hline & B. & $*$ & * & $*$ & $*$ & $*$ & $*$ & $*$ & $*$ & $*$ & $*$ & $*$ & * & 7.33 \\
\hline & $\mathrm{N}$. & $*$ & * & * & $*$ & $*$ & $*$ & - & $*$ & $*$ & $*$ & $*$ & $*$ & 5.06 \\
\hline & M. & $*$ & $*$ & $*$ & $*$ & $*$ & $*$ & $*$ & $*$ & $*$ & $*$ & $*$ & $*$ & 12.58 \\
\hline \multirow{4}{*}{ Coccus hesperidum } & S. & $*$ & $*$ & $*$ & - & - & - & - & $*$ & $*$ & $*$ & $*$ & $*$ & 2.69 \\
\hline & B. & $*$ & $*$ & $*$ & $*$ & - & - & - & - & $*$ & $*$ & $*$ & $*$ & 3.01 \\
\hline & $\mathrm{N}$. & $*$ & $*$ & $*$ & - & $*$ & - & - & $*$ & $*$ & $*$ & - & $*$ & 1.73 \\
\hline & M. & $*$ & $*$ & - & $*$ & $*$ & - & $*$ & $*$ & $*$ & $*$ & $*$ & $*$ & 6.93 \\
\hline \multirow{4}{*}{ Coccus longulus } & S. & - & - & - & - & - & - & - & - & - & - & - & - & 0.00 \\
\hline & B. & - & - & - & - & - & - & - & - & - & - & - & - & 0.00 \\
\hline & $\mathrm{N}$. & - & - & - & - & - & - & - & - & - & - & $*$ & - & 0.35 \\
\hline & M. & - & - & - & - & - & - & - & $*$ & - & - & - & - & 0.30 \\
\hline \multirow{4}{*}{ Saissetia coffeae } & S. & - & - & $*$ & - & - & - & - & - & - & - & - & - & 0.00 \\
\hline & B. & - & - & - & - & - & - & - & - & - & - & - & - & 0.00 \\
\hline & $\mathrm{N}$. & - & - & - & - & - & - & - & - & - & - & - & - & 0.00 \\
\hline & M. & - & - & - & - & - & - & - & - & - & - & - & - & 0.43 \\
\hline \multirow{4}{*}{ Saissetia oleae } & S. & - & - & - & - & - & - & - & - & - & - & - & - & 0.00 \\
\hline & B. & $*$ & - & - & - & - & - & - & - & - & - & - & - & 0.08 \\
\hline & $\mathrm{N}$. & - & - & - & - & - & - & - & - & - & - & - & - & 0.00 \\
\hline & M. & - & - & - & - & - & - & - & - & - & - & - & - & 0.00 \\
\hline \multirow{4}{*}{ Aonidiella aurantii } & S. & $*$ & $*$ & $*$ & $*$ & $*$ & $*$ & $*$ & $*$ & $*$ & $*$ & $*$ & $*$ & 13.84 \\
\hline & B. & $*$ & $*$ & $*$ & $*$ & $*$ & $*$ & $*$ & $*$ & $*$ & $*$ & $*$ & $*$ & 11.67 \\
\hline & $\mathrm{N}$. & $*$ & $*$ & $*$ & $*$ & $*$ & $*$ & $*$ & $*$ & $*$ & $*$ & $*$ & $*$ & 11.99 \\
\hline & M. & $*$ & $*$ & - & $*$ & $*$ & $*$ & $*$ & $*$ & $*$ & $*$ & $*$ & * & 15.55 \\
\hline \multirow{4}{*}{ Chrysomphalus aonidum } & S. & $*$ & $*$ & $*$ & $*$ & $*$ & $*$ & $*$ & $*$ & $*$ & $*$ & - & $*$ & 6.90 \\
\hline & B. & $*$ & $*$ & $*$ & $*$ & $*$ & $*$ & $*$ & $*$ & $*$ & $*$ & $*$ & - & 11.36 \\
\hline & $\mathrm{N}$. & $*$ & $*$ & $*$ & $*$ & $*$ & $*$ & $*$ & - & $*$ & $*$ & $*$ & $*$ & 7.84 \\
\hline & M. & $*$ & * & $*$ & - & $*$ & $*$ & - & * & $*$ & $*$ & - & - & 9.20 \\
\hline \multirow{4}{*}{ Lepidosaphes beckii } & S. & $*$ & $*$ & $*$ & $*$ & $*$ & $*$ & $*$ & $*$ & $*$ & $*$ & $*$ & $*$ & 44.75 \\
\hline & B. & $*$ & $*$ & $*$ & - & $*$ & $*$ & $*$ & * & $*$ & $*$ & $*$ & $*$ & 30.26 \\
\hline & $\mathrm{N}$. & $*$ & $*$ & $*$ & $*$ & $*$ & $*$ & $*$ & $*$ & $*$ & $*$ & $*$ & $*$ & 54.46 \\
\hline & M. & $*$ & $*$ & $*$ & $*$ & $*$ & $*$ & $*$ & $*$ & $*$ & $*$ & $*$ & $*$ & 35.15 \\
\hline \multirow{4}{*}{ Parlatoria pergandii } & S. & $*$ & $*$ & $*$ & $*$ & * & $*$ & $*$ & $*$ & $*$ & * & $*$ & $*$ & 26.62 \\
\hline & B. & $*$ & $*$ & $*$ & $*$ & $*$ & $*$ & $*$ & $*$ & $*$ & $*$ & $*$ & $*$ & 35.94 \\
\hline & $\mathrm{N}$. & $*$ & $*$ & $*$ & $*$ & $*$ & $*$ & $*$ & $*$ & $*$ & $*$ & $*$ & $*$ & 17.91 \\
\hline & M. & $*$ & $*$ & $*$ & $*$ & $*$ & $*$ & $*$ & $*$ & - & - & $*$ & $*$ & 18.05 \\
\hline \multirow{4}{*}{ Icerya purchasi } & S. & - & - & - & - & - & - & - & - & $*$ & $*$ & - & $*$ & 0.11 \\
\hline & B. & - & - & - & - & - & - & - & - & - & - & - & - & 0.00 \\
\hline & $\mathrm{N}$. & $*$ & - & $*$ & - & - & - & - & - & - & - & - & - & 0.46 \\
\hline & M. & $*$ & $*$ & $*$ & - & $*$ & - & - & - & - & - & - & - & 1.69 \\
\hline \multirow{4}{*}{ Icerya seychellarum } & $\mathrm{S}$. & - & - & - & - & - & - & - & - & - & - & - & - & 0.00 \\
\hline & B. & - & - & - & - & - & - & - & - & - & - & - & - & 0.00 \\
\hline & $\mathrm{N}$. & - & - & - & - & - & - & - & - & - & - & - & - & 0.00 \\
\hline & M. & - & - & - & - & - & - & - & - & - & - & - & - & 0.00 \\
\hline \multirow{4}{*}{ Planococcus citri } & S. & - & $*$ & - & - & $*$ & $*$ & $*$ & - & - & - & - & - & 0.55 \\
\hline & B. & - & $*$ & - & - & $*$ & $*$ & $*$ & - & - & - & - & - & 0.35 \\
\hline & $\mathrm{N}$. & $*$ & - & - & - & $*$ & - & - & - & - & - & - & - & 0.21 \\
\hline & M. & - & - & - & - & $*$ & - & - & - & - & - & - & - & 0.12 \\
\hline
\end{tabular}

$\begin{array}{lll}\text { S. }=\text { Succari orange } & \text { B. }=\text { Baladi orange } \quad \text { N. =Navel orange } \quad \text { M. = Mandarin }\end{array}$ 
Table 3. Occurrence dates of scale insects and mealy bugs infested four varieties of citrus trees at El Beheira during 2012-2013

\begin{tabular}{|c|c|c|c|c|c|c|c|c|c|c|c|c|c|c|}
\hline \multirow[t]{2}{*}{ Coccoid sp. } & \multirow[b]{2}{*}{ Var. } & \multicolumn{12}{|c|}{ Months } & \multirow[t]{2}{*}{ Mean $(\%)$} \\
\hline & & Feb. & M. & A. & M. & $\mathbf{J}$. & July & A. & S. & o. & N. & D. & Jan. & \\
\hline \multirow{4}{*}{ Ceroplastes floridensis } & S. & $*$ & $*$ & - & $*$ & $*$ & $*$ & $*$ & $*$ & $*$ & $*$ & $*$ & $*$ & 6.94 \\
\hline & B. & $*$ & $*$ & - & $*$ & $*$ & $*$ & * & $*$ & $*$ & $*$ & * & * & 15.94 \\
\hline & N. & $*$ & $*$ & - & $*$ & $*$ & $*$ & $*$ & $*$ & $*$ & $*$ & $*$ & $*$ & 7.89 \\
\hline & M. & $*$ & - & $*$ & $*$ & $*$ & $*$ & $*$ & $*$ & $*$ & $*$ & $*$ & $*$ & 12.91 \\
\hline \multirow{4}{*}{ Coccus hesperidum } & S. & - & $*$ & - & - & - & - & - & - & - & - & - & - & 0.03 \\
\hline & B. & - & $*$ & * & - & - & - & - & - & - & - & - & - & 0.58 \\
\hline & $\mathrm{N}$. & $*$ & $*$ & - & - & - & - & - & - & - & $*$ & - & - & 0.19 \\
\hline & M. & $*$ & $*$ & - & $*$ & $*$ & - & - & - & - & - & - & - & 1.36 \\
\hline \multirow{4}{*}{ Coccus longulus } & S. & - & - & - & - & - & - & - & - & - & - & - & - & 0.00 \\
\hline & B. & - & - & - & - & - & - & - & - & - & - & - & - & 0.00 \\
\hline & $\mathrm{N}$. & - & - & - & - & $*$ & $*$ & - & - & $*$ & - & - & - & 0.12 \\
\hline & M. & - & - & - & - & - & - & - & - & - & - & $*$ & - & 0.09 \\
\hline \multirow{4}{*}{ Saissetia coffeae } & S. & - & - & $*$ & - & - & - & - & - & - & - & - & - & 0.00 \\
\hline & B. & - & - & $*$ & - & - & - & - & - & - & - & - & - & 0.30 \\
\hline & $\mathrm{N}$ & - & - & - & - & - & - & - & - & $*$ & - & - & - & 0.03 \\
\hline & M. & - & - & $*$ & - & - & - & $*$ & - & - & - & - & - & 1.02 \\
\hline \multirow{4}{*}{ Saissetia oleae } & S. & - & - & - & - & - & - & - & - & - & - & - & - & 0.00 \\
\hline & B. & - & - & - & - & - & - & - & - & - & - & - & - & 0.00 \\
\hline & $\mathrm{N}$. & - & - & - & - & - & - & - & - & - & - & - & - & 0.00 \\
\hline & M. & - & - & - & - & - & - & - & - & - & - & - & - & 0.00 \\
\hline \multirow{4}{*}{ Aonidiella aurantii } & S. & $*$ & $*$ & $*$ & $*$ & $*$ & $*$ & $*$ & $*$ & $*$ & $*$ & $*$ & $*$ & 12.58 \\
\hline & B. & $*$ & $*$ & $*$ & $*$ & $*$ & $*$ & $*$ & $*$ & $*$ & $*$ & $*$ & $*$ & 14.29 \\
\hline & $\mathrm{N}$. & $*$ & $*$ & $*$ & $*$ & $*$ & $*$ & $*$ & $*$ & $*$ & $*$ & $*$ & $*$ & 14.01 \\
\hline & M. & $*$ & $*$ & $*$ & $*$ & - & $*$ & $*$ & $*$ & $*$ & $*$ & $*$ & $*$ & 14.41 \\
\hline \multirow{4}{*}{ Chrysomphalus aonidum } & S. & - & - & - & $*$ & - & $*$ & $*$ & - & $*$ & $*$ & $*$ & $*$ & 4.87 \\
\hline & B. & - & - & - & $*$ & $*$ & $*$ & $*$ & $*$ & $*$ & $*$ & $*$ & $*$ & 14.23 \\
\hline & N. & $*$ & $*$ & * & $*$ & - & $*$ & $*$ & $*$ & $*$ & $*$ & $*$ & $*$ & 5.23 \\
\hline & M. & $*$ & - & - & $*$ & $*$ & $*$ & $*$ & - & $*$ & $*$ & * & $*$ & 9.94 \\
\hline \multirow{4}{*}{ Lepidosaphes beckii } & S. & $*$ & $*$ & $*$ & $*$ & $*$ & $*$ & $*$ & $*$ & $*$ & $*$ & $*$ & $*$ & 48.03 \\
\hline & B. & $*$ & $*$ & $*$ & $*$ & $*$ & $*$ & $*$ & $*$ & $*$ & $*$ & $*$ & * & 30.35 \\
\hline & $\mathrm{N}$. & $*$ & $*$ & $*$ & $*$ & $*$ & $*$ & $*$ & $*$ & $*$ & $*$ & $*$ & * & 52.12 \\
\hline & M. & $*$ & $*$ & $*$ & $*$ & $*$ & $*$ & $*$ & $*$ & $*$ & $*$ & $*$ & $*$ & 39.93 \\
\hline \multirow{4}{*}{ Parlatoria pergandii } & S. & $*$ & $*$ & $*$ & $*$ & $*$ & $*$ & $*$ & $*$ & $*$ & $*$ & $*$ & $*$ & 26.22 \\
\hline & B. & $*$ & $*$ & $*$ & $*$ & $*$ & $*$ & $*$ & $*$ & $*$ & $*$ & $*$ & $*$ & 22.06 \\
\hline & $\mathrm{N}$. & $*$ & $*$ & $*$ & $*$ & $*$ & - & $*$ & $*$ & $*$ & $*$ & $*$ & $*$ & 19.71 \\
\hline & M. & - & $*$ & $*$ & $*$ & $*$ & $*$ & $*$ & $*$ & $*$ & $*$ & $*$ & $*$ & 17.62 \\
\hline \multirow{4}{*}{ Icerya purchasi } & S. & - & $*$ & - & - & - & - & - & $*$ & - & - & - & - & 0.59 \\
\hline & B. & - & $*$ & $*$ & $*$ & - & - & - & $*$ & - & - & - & - & 0.98 \\
\hline & $\mathrm{N}$. & - & - & - & - & - & - & $*$ & - & - & - & - & - & 0.05 \\
\hline & M. & - & - & - & - & $*$ & $*$ & - & $*$ & - & - & - & - & 1.07 \\
\hline \multirow{4}{*}{ Icerya seychellarum } & S. & - & - & - & - & $*$ & - & - & - & - & $*$ & - & - & 0.21 \\
\hline & B. & - & - & - & $*$ & $*$ & $*$ & $*$ & - & - & $*$ & - & - & 0.59 \\
\hline & $\mathrm{N}$. & - & $*$ & $*$ & - & - & - & - & $*$ & - & $*$ & - & - & 0.28 \\
\hline & M. & - & - & - & $*$ & - & - & - & - & - & - & - & - & 0.27 \\
\hline \multirow{4}{*}{ Planococcus citri } & S. & - & - & - & $*$ & $*$ & - & $*$ & $*$ & - & * & - & - & 0.51 \\
\hline & B. & - & $*$ & - & $*$ & $*$ & $*$ & - & - & - & - & - & - & 0.67 \\
\hline & $\mathrm{N}$. & $*$ & - & - & - & $*$ & - & $*$ & - & - & - & - & - & 0.36 \\
\hline & M. & - & - & - & - & $*$ & $*$ & - & - & - & $*$ & $*$ & - & 1.36 \\
\hline
\end{tabular}

S. =Succari orange $\quad$ B. = Baladi orange $\quad$ N. =Navel orange $\quad$ M. =Mandarin 


\section{9-The chaff scale, Parlatoria pergandii Comstock}

During the period of the present study, chaff scale observed on all the four varieties of citrus all over the year.

It was disappeared in October and November 2011 on Mandarin. The chaff scale represented by 26.62 , $35.94,17.91$ and $18.05 \%$ of mean number in the first year, for Succari, Baladi, Navel orange and Mandarin, respectively. In the second year, it represented 26.22, $22.06,19.71$ and $17.62 \%$ of total count on the same citrus species, respectively (Table2\&3).

\section{Family Monophlebidae:}

\section{Cottony Cushion scale, Icerya purchasi purchasi Maskell}

It was recorded and described in Egypt by Hall (1922 and 1923); CABI (1971), Ezzat and Nada (1986).

Table (2\&3) show that cottony cushion scale found in rare state on four citrus varieties. In the first year, it was found on Succari orange in January October and November; with $0.11 \%$ of total count. On Navel orange, it was observed in February and April with $0.59 \%$ of total count, while on Mandarin it was recorded from February and April and in June, with 1.69 of total count in the first year.

In the second year, it was associated with Succari orange in March and September with $0.59 \%$ of total count and with Baladi orange during March - May and September $(0.98 \%$ of total count $)$; while it was observed on Navel orange in August ( $0.05 \%$ of total count) and with Mandarin in June, July and September, 2012 with $1.07 \%$ of total count (Table2\&3).

\section{Seychellarum mealybug, Icerya Seychellarum Seychellarum (Westwood)}

In the present study, it was observed only in the second year (2012) associated with Succari orange (June and November); Baladi orange (May to August and November); Navel orange (March, April; September and November) and with Mandarin in May. The mean numbers were low reached $0.21,0.59,0.28$ and $0.27 \%$ on Succari, Baladi, Navel oranges and Mandarin, respectively (Table 3 ).

\section{Family Pseudococcidae}

\section{Citrus mealy bug, Planococcus citri (Risso)}

Ahmed and Abd-Rabou (2010) reported that citrus mealybug infested 65 plant species belonging to 56 genera in Egypt.

In the present work, citrus mealybug was found associated with citrus varieties in low number. It was observed in the first growing season on Succari orange
(March, June to August); on Baladi orange (March, June to August); on Navel orange (February and June), and on Mandarin (June). It was represented 0.55, 0.35, 0.21 and $0.12 \%$ of total count for Succari, Baladi; Navel oranges and Mandarin, respectively (Table2).

In the second year, it was observed associated with Succari orange during May, June, August, September and November while Baladi one in March and May to July; with Navel in February, June and August; while with Mandarin, it observed during June, July, November and December. It reached 0.51, 0.67, 0.36 and $1.36 \%$ of total count on Succari, Baladi, Navel oranges and Mandarin, respectively (Table3).

\section{REFERENCES}

Ahmed, N. H. and S. M. Abd-RAbuu (2010). Host plants, geographical distribution, natural enemies and biological studies of the citrus mealybug, Placoccus citri (Risso) (Hemiptera: Pseudococcidae). Egyptian Acad. J. Bio.1.Sci., 3: 39- 47.

Al-Khaldy Amal, N (2003) Survey and dispersal of oriental yellow scale insect Aonidiella orientalis (Newst.) on citrus in central Iraq

(http://www.arabsciEntomist.org/english/page/490/)

CAB Inter. Nat. (1971). Icerya purchasi (Mask). Distribution maps of pests, series A, Agric. 51: 3.

Balochowsky, A.S. (1932). Contributions a L'etude des coccides de L' Africque mineure (3m note). Bul. SOC. d' Hist . Nat. Africque du Nord 19: 156-180.

Ezzat, Y. M. (1958). Classification of the scale insects, family Diaspididae, as kwn to occur in Egypt (Homoptera: Coccoidea). Bull. de la Société Entomogiqued'Egypte, 42: 233-251.

Ezzat, Y.M. (1959): A new planococcine mealybug on statice from Egypt (Homoptera: Coccoidea-Pseudococcidae). Bull. Soc Ent. Egypt, 43: 401-404.

Ezzat, Y. M. and N. A. Hussein (1969). Redescription and classification of the family Coccidae in U.A.R. (Homoptera: Coccidae). Bull. Soc. Ent. Egypt. 51: 395426.

Ezzat, Y. M. and S. M. A. Nada (1986). List of super family Coccoidea as known to exist in Egypt. Bull. Lab. Entomol. Agr. "Filippo Silvestri", 43: 85-90.

Gill, R. J. (1997). The scale insects of California:The armored scales (Homoptera:Coccoidea). Technical series in Agric. biosystematics and plant pathology depart. Entom. of food and Agric., Sacra. Entom. California, USA. 307.

Habib, A. and Y. H. Attalah (1960) .Population studies on the black scale Chrysomphalus ficus Ashm. The buildup of the population on different kinds of citrus. Bull. Soc. Ent. Egypte, 29: 13-19. 
Habib, A.; H. S. Salama and A. H. Amin (1972). The buildup of population of the red scale Aonidiella aurantii (Maskell) on citrus trees in Egypt. Zeitschrift für Angewandte Entomogie, 70: 378-385.

Hafez, M. and H. S. Salama (1969). Biology of the citrus purple scale, Lepidosaphes beckii Newm in Egypt (Hemiptera:Coccoidea). Bull. Soc. Entom. Egypte., 53: 517-532.

Hall, W. J. (1922). Observations on the Coccidae of Egypt. Tech. and Sc. Bull. 22. Minst. Agric.

Hall, W. J. (1923). Further observations on the Coccidae of Egypt. Tech. Sc-Bull., 22. Ministry Agric. Egypt.
Hamom, A. B. and M. L. Williams (1984). The soft scale insects of Florida (Homoptera: Coccoidea: Coccidae). In: Arthropods of Florida and Neighboring Land Areas. Dept. Agric. and Consumer Serv. Div. Plant Ind., Gaines ville. 194.

Podoler, H.; Y. Dreishpoun and D. Rosen (1981). Population dynamics of the Florida wax scale, Ceroplastes floridensis (Homoptera: Coccidae) on citrus in Israel. Acta Oecologica, Oecologia Applicata., 2: 81-91

Willcocks, F. C. (1922). A survey of the more important insects and mites of Egypt with notes on the life-history, habits, natural enemies and suggestions for control. Sultanic Agric. Sec., Bull. 1:169.

Wing-Feng. (1999). Occurrence of the citrus brown-round scale and its control in the northern part of Guangxi. South China Fruits. 28(2): 23.

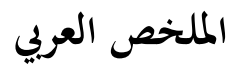

\section{الحشرات القشرية والبق الدقيقي المرتبطة بأشجار الموالح في محافظة البحيرة، مصر}

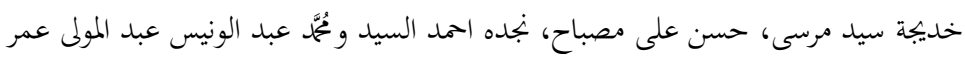

Coccoidea

السكرى والبلدي وابوسرة واليوسفي، واتضح ان اكثر هذه الحشرات

انتشارا هي حشرة الموالح الارجوانية واكثر الموالح حساسية للإصابة هو

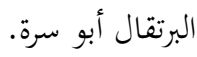

$$
\begin{aligned}
& \text { أجريت هذه الدراسة لحصر الحشرات القشرية والبق الدقيقي على } \\
& \text { أربعة أنواع من أشجار الموالح وتحديد النسبة المئوية للإصابة لكل منها } \\
& \text { وذلك خلال عامين من } 2011 \text { الى } 2013 \text { وقد أظهرت النتائج } \\
& \text { المتحصل عليها أن مجموع اثني عشر حشرة من الحشرات القشرية والبق } \\
& \text { دقيقي تتبع تسعة أجناس تنتمي إلى أربع عائلات تابعة لفوق عائلة }
\end{aligned}
$$

